NBER WORKING PAPER SERIES

\title{
VENTURE CAPITALISTS AS PRINCIPALS: CONTRACTING, SCREENING, AND MONITORING
}

\author{
Steven N. Kaplan \\ Per Strömberg
}

Working Paper 8202

http://www.nber.org/papers/w8202

\author{
NATIONAL BUREAU OF ECONOMIC RESEARCH \\ 1050 Massachusetts Avenue \\ Cambridge, MA 02138 \\ April 2001
}

This research has been supported by the Kauffman Foundation, by the Lynde and Harry Bradley Foundation and the Olin Foundation through grants to the Center for the Study of the Economy and the State, and by the Center For Research in Security Prices. Address correspondence to Per Strömberg, Graduate School of Business, The University of Chicago, 1101 East 58th Street, Chicago, IL 60637 or e-mail at per.stromberg@gsb.uchicago.edu. The views expressed herein are those of the authors and not necessarily those of the National Bureau of Economic Research.

(C) 2001 by Steven N. Kaplan and Per Strömberg. All rights reserved. Short sections of text, not to exceed two paragraphs, may be quoted without explicit permission provided that full credit, including $\odot$ notice, is given to the source. 
Venture Capitalists As Principals: Contracting, Screening, and Monitoring

Steven N. Kaplan and Per Strömberg

NBER Working Paper No. 8202

April 2001

JEL No. G24, G32

\begin{abstract}
Theoretical work on the principal-agent problem in financial contracting focuses on the conflicts of interest between an agent / entrepreneur with a venture that needs financing, and a principal / investor providing funds for the venture. Theory has identified three primary ways that the investor / principal can mitigate these conflicts - structuring financial contracts, pre-investment screening, and post-investment monitoring and advising. In this paper, we describe recent empirical work and its relation to theory for one prominent class of principals - venture capitalists (VCs).

The empirical studies indicate that VCs attempt to mitigate principal-agent conflicts in the three ways suggested by theory. The evidence also shows that contracting, screening, and monitoring are closely interrelated. In screening, the VCs identify areas where they can add value through monitoring and support. In contracting, the VCs allocate rights in order to facilitate monitoring and minimize the impact of identified risks. Also, the equity allocated to VCs provides incentives to engage in costly support activities that increase upside values, rather than just minimizing potential losses. There is room for future empirical research to study these activities in greater detail for VCs, for other intermediaries such as banks, and within firms.
\end{abstract}

Steven N. Kaplan

Graduate School of Business

University of Chicago

1101 East $58^{\text {th }}$ Street

Chicago, IL 60637

steven.kaplan@gsb.uchicago.edu
Per Strömberg

Graduate School of Business

University of Chicago

1101 East $58^{\text {th }}$ Street

Chicago, IL 60637

per.stromberg@gsb.uchicago.edu 
There is a large academic literature on the principal-agent problem in financial contracting. ${ }^{1}$ This literature focuses on the conflicts of interest between an agent, who is an entrepreneur with a venture that needs financing, and a principal, who is the investor providing the funds for the venture. Theory has identified a number of ways that the investor / principal can mitigate these conflicts. First, the investor can structure financial contracts, i.e. the allocation of cash flow and control rights, between the entrepreneur and investor to provide incentives for the entrepreneur to behave optimally. Second, the investor can engage in information collection before deciding whether to invest, in order to screen out ex ante unprofitable projects and bad entrepreneurs. And third, the investor can engage in information collection and monitoring once the project is under way.

Despite the large volume of theory, empirical work has lagged behind in comparing the contracts and actions of real world principals to their counterparts in financial contracting theory. In this paper, we describe recent empirical work and its relation to theory for one prominent class of such principals - venture capitalists (VCs). In our view, VCs are real world entities that closely approximate the investors of theory. VCs invest in entrepreneurs who need financing to fund a promising project or company. VCs have strong incentives to maximize value, but, at the same time, receive few or no private benefits of control. Although they are intermediaries, VCs typically receive at least $20 \%$ of the profits on their portfolios. ${ }^{2}$

In addition to being interesting from a theoretical perspective, $\mathrm{VC}$ actions and contracts of are interesting from a practical perspective. VCs have been extremely successful in the last several years: (1) they have been associated with a number of the prominent corporate successes 
like Ariba, Cisco, eBay, and Yahoo; (2) they have generated substantial returns and wealth for their investors; and (3) they have raised and invested record amounts of money.

\section{Contracting}

In Kaplan and Strömberg (2000a), we compare the characteristics of real world financial contracts to their counterparts in financial contracting theory. ${ }^{3}$ We do so by conducting a detailed study of actual contracts between VCs and entrepreneurs. For 213 VC investments in 119 portfolio companies by $14 \mathrm{VC}$ firms, the VC firm provided the contractual agreements governing each financing round in which the firm participated. The VC firm also provided (if available) the company's business plan, internal analyses evaluating the investment, and information on subsequent performance.

We obtain the following findings.

First, a key feature of VC financings is that they allow VCs to separately allocate cash flow rights, voting rights, board rights, liquidation rights, and other control rights. We explicitly measure and report the allocation of these rights.

Second, while convertible securities are used most frequently, VCs also implement the same set of rights using combinations of multiple classes of common stock and straight preferred stock. We also note that VCs use a variant of convertible preferred called participating preferred in roughly $40 \%$ of the financings. Participating preferred, under most circumstances, behaves more like a position of straight preferred stock and common stock than a position of convertible preferred. Hence, the VC claim corresponds in most cases to a holding of (zero-coupon) debt and voting equity. 
Third, cash flow rights, voting rights, control rights, and future financings are frequently contingent on observable measures of financial and non-financial performance. These state contingencies are more common in the early stages of the VC-entrepreneur relationships.

Fourth, voting rights, board rights and liquidation rights are allocated such that if the company performs poorly, the VCs obtain full control. As company performance improves, the entrepreneur retains / obtains more control rights. If the company performs very well, the VCs retain their cash flow rights, but relinquish most of their control and liquidation rights. Ex ante, the investors are likely to be in control in more states of the world for early stage ventures that have not yet started to generate revenues, while previously successful entrepreneurs get to retain more control in their new ventures.

Fifth, we find that it is common for VCs to include non-compete and vesting provisions that make it more expensive for the entrepreneur to leave the firm, thus mitigating the potential hold-up problem between the entrepreneur and the investor. Vesting provisions are more common in early stage financings where it is more likely that the hold-up problem is more severe.

Finally, we find that cash flow incentives, control rights, and contingencies implemented in these contracts are used more as complements than as substitutes. Ventures in which the VCs have voting and board majority are also more likely to have the entrepreneur's equity claim as well as the release of committed funds being contingent on performance milestones.

Our results have the following implications:

First, cash flow rights matter in a way that is consistent with the principal-agent theories of Holmström (1979), Harris and Raviv (1979), Lazear (1986), and others. VCs change the 
entrepreneur's equity compensation function, making it more sensitive to performance when incentive and asymmetric information problems are more severe.

Second, the allocation of control rights between the VC and the entrepreneur is a central feature of the financial contracts. This strongly suggests that despite the prevalence of contingent contracting, contracts are inherently incomplete. This finding gives support to the incomplete contracting approach pioneered by Grossman and Hart (1986) and Hart and Moore (1990 and 1998).

Third, cash flow rights and control rights can be separated and made contingent on observable and verifiable measures of performance. This is most supportive of theories that predict shifts of control to investors in different states, such as Aghion and Bolton (1992) and Dewatripont and Tirole (1994).

Fourth, the widespread use of non-compete and vesting provisions indicates that VCs care about the hold-up problem explored in Hart and Moore (1994).

Finally, we think our results suggest fruitful avenues for future theoretical research. In particular, the results indicate that the allocations of cash flow, control and liquidation rights shift gradually toward the entrepreneur as performance improves. These allocations also are interrelated. For example, Hart (2000) suggests that effort considerations should be added to the control considerations in Aghion and Bolton (1992).

\section{Screening}

Before the closing of the investment and the design of the financial contracts, however, the VCs spend a significant amount of time and effort evaluating and screening the investment opportunity. Kaplan and Strömberg (2000b) focus empirically on this information collection and 
screening process by studying a sample of VC investments in portfolio companies. To help the $\mathrm{VC}$ partnership evaluate an investment in a company, it is common for the individual venture capitalist who is sponsoring the investment to prepare a detailed investment analysis or memorandum for the other partners. In preliminary work, we analyze the investment memoranda from ten $\mathrm{VC}$ partnerships for 58 investments in 42 portfolio companies. We complement our analysis with information from the company business plans, as well as data on the financial contracts from Kaplan and Strömberg (2000a).

First, we consider how VC screening actually works. The VC analyses invariably include a set of investment theses or rationales for making the investment. We find evidence consistent with academic and practitioner accounts that VCs explicitly consider the attractiveness of the opportunity - the market size, the strategy, the technology, customer adoption, and competition - the management team, and the contract terms. The analyses also typically describe the risks in the investment theses. We then consider the investment evaluation process in more detail by describing and summarizing individual analyses: market, technology, customer adoption, competition, and management. In particular, management risk is one of the most common sources of uncertainty that the $\mathrm{VC}$ identifies. It is present in more that $60 \%$ of the sample investments. This sometimes reflects a concern with the founder's incentives, e.g. that the founder seems to show a lack of focus or have a difficult personality. More often, however, the concern is less about undesirable characteristics of the founders and more about the management team being incomplete in some sense. It is very common that the VCs identifies a need to complete the management team with experienced executives.

Second, we consider whether and how the screening analyses interact with the design of the financial contracts. We consider whether and how the VCs adjust the allocations of control, 
cash flow rights, and the staging of the committed funds to reflect differences in perceived quality and perceived risks. Of the different risk factors, management risk is the factor affecting the contracts most strongly and consistently. When management risk is present, the VCs ensure that the contractual structure provides a higher degree of control to the VCs, both in terms of votes and board seats, as well as a higher fraction of the committed financing being withheld if performance milestones are not met.

Finally, we examine the relation between the ultimate investment outcome / performance and the VC's initial analysis of the company. On the margin, one might expect there to be no relation because the contracts (and valuations) would adjust to differences in quality and risk. However, if VCs have some monopoly power, if some investments are inframarginal, or if VCs, too, are learning, a relation could exist. We find evidence suggesting that the VC's initial appraisal of the management team is related to subsequent performance. Portfolio companies with strong management teams are more likely to go public.

These results confirm that VCs expend a great deal of time and effort in evaluating and screening transactions. This is consistent with anecdotal accounts that the scarcest commodity a VC has is time not capital. ${ }^{4}$ This suggests that theoretical models can benefit by including investor costs of evaluating potential investments and by assuming that investors are particularly well-informed. ${ }^{5}$

\section{Monitoring}

Finally, several recent papers focus on post-investment information collection, monitoring, and other actions by the VC. Anecdotal accounts stress an important role for VCs in monitoring management, finding management, and providing advice. ${ }^{6}$ 
Lerner (1995) finds that VCs are more likely to join or be added to the boards of private companies in periods when the chief executive officer (CEO) of the company changes. He interprets this as evidence of $\mathrm{VC}$ monitoring.

Hellman and Puri (2000a) study a hand-collected sample of 173 start-up firms from California's Silicon Valley. They find that venture capital is associated with a significant reduction in the time to bring a product to market. They provide some evidence that this association holds after controlling for $\mathrm{VC}$ ability to select more successful company.

Hellman and Puri (2000b) study another aspect of the same data set. They find that VCfinanced firms are more likely and faster to professionalize by adopting stock option plans and hire a vice president of sales. They also find VC-financed firms are more likely and faster to bring in CEOs from outside the firm.

The three studies described in the previous paragraphs find indirect evidence of postfinancing VC actions. Kaplan and Strömberg (2000b) complement these studies by presenting direct evidence on $\mathrm{VC}$ actions or monitoring. We rely on the investment analyses at the time of the initial investment that describe actions that the $\mathrm{VC}$ took before investing and that the $\mathrm{VC}$ expects to undertake conditional on investing. In addition, for a subset of the portfolio companies, we describe subsequent status reports on the investments. These reports summarize undertaken and anticipated monitoring actions.

Our primary finding is to confirm that VCs play a large role in shaping and recruiting the senior management team. In $14 \%$ of the investments, the VC plays a role in shaping the management team before investing and in $50 \%$ of the investments, the VC explicitly expects to play a role after investing. Sometimes this involves replacing a founding manager, but more often it is an issue of strengthening and broadening the existing management team by hiring 
experienced executives. Moreover, in more than a third of the investments the VC expects to be active in other areas, such as develop a business plan, assist with acquisitions, facilitate strategic relationships with other companies, or designing employee compensation.

Because the investment memoranda vary in the amount of detail they provide and because they only mention the monitoring actions that are expected ex ante, these numbers almost certainly understates the VCs' monitoring and support activities. Still, there seem to be limits to the extent to which VCs are willing to monitor and support their portfolio companies. The risks of high monitoring costs or involvement costs are particularly interesting. In about $20 \%$ of the investments, the VC was worried that the investment might require too much time. In two cases, this involved the VC becoming chairman of the company. This indicates that while VCs regularly play a monitoring and advisory role, they do not intend to become too involved in the company.

Overall, these studies corroborate the anecdotal evidence that VCs exert effort in monitoring and aiding the companies in which they invest. In addition to actions traditionally associated with investor monitoring, such as replacing management after poor performance, there is substantial evidence of VCs assisting the founders in running and professionalizing the business, what Hellman \& Puri (2000b) term the supporting role of venture capital. From a theoretical perspective, these studies suggest that certain types of investors (such as VCs) should be modeled as exerting costly effort to improve outcomes. ${ }^{7}$

\section{Implications and Conclusion}

The empirical studies of venture capitalists indicate that venture capitalists attempt to mitigate principal-agent conflicts in the three ways suggested by theory - through sophisticated 
contracting, pre-investment screening, and post-investment monitoring and advising. The evidence also suggests that contracting, screening, and monitoring are closely interrelated. In the screening process, the VCs identify areas where they can add value through monitoring and support. In the contracting stage, the VCs allocate rights in order to facilitate monitoring and minimize the impact of the identified risk factors, e.g. by allocating more control to investors when management is weak, or make founder cash flow rights and release of funds contingent on management actions. Also, the allocations of equity to VCs provide incentives to engage in costly support activities that increase the upside value of the venture, rather than just minimizing potential losses. There is room for future empirical research to study these activities in greater detail for VCs, for other intermediaries such as banks and within firms.

The empirical studies also suggest two avenues for additional theoretical research. First, such research can better illuminate the rationales behind the actual contracts that are written. Understanding the interaction and complementarity between different types of cash flow, control and liquidation rights seems particularly relevant. Dewatripont and Tirole (1994) and Hart (2000) are important first steps. Second, such research should take into account the fact that VCs exert costly effort both in pre-investment screening and post-investment monitoring / advising, and that these activities affects the design of the financial contracts. 


\section{References}

Aghion, Phillippe, and Patrick Bolton. "An incomplete contracts approach to financial contracting." Review of Economic Studies, 1992, 77, pp. 338-401.

Black, Bernard and Ronald Gilson. "Venture capital and the structure of capital markets: Banks versus stock Markets." Journal of Financial Economics, 1998, 47(3), pp. 243.277.

Bolton, Patrick, and David Scharfstein. "A theory of predation based on agency problems in financial Contracting." American Economic Review, 1990, 80, pp. 94-106.

Dewatripont, Matthias, and Jean Tirole. " A theory of debt and equity: Diversity of securities and managershareholder congruence.” Quarterly Journal of Economics, 1994, 109, pp. 1027-1054.

Garmaise, Mark. "Informed Investors and the Financing of Entrepreneurial Projects." Working paper, University of Chicago, 1999.

Gladstone, David. Venture Capital Handbook. Englewood Cliffs, NJ: Prentice Hall, 1988.

Gompers, Paul. “An Examination of Convertible Securities in Venture Capital Investments.” Working paper, Harvard Business School, 1998.

Gompers, Paul and Josh Lerner. The Venture Capital Cycle. Cambridge, MA: MIT Press, 1999.

Gorman, M. and William Sahlman. "What Do Venture Capitalists Do?" Journal of Business Venturing, 1989, 4, pp. 231-248.

Grossman, Sanford, and Oliver Hart. "The costs and benefits of ownership: A theory of vertical and lateral Integration.” Journal of Political Economy, 1986, 94, pp. 691-719.

Harris, Milton, and Artur Raviv. "Optimal incentive contracts with imperfect information." Journal of Economic Theory, 1979, 20, pp. 231-259.

Hart, Oliver. "Financial Contracting." Working paper, Harvard University, October 2000.

Hart, Oliver, and John Moore. "Property rights and the Nature of the Firm.” Journal of Political Economy, 1990, 98, pp. $1119-1158$.

Hart, Oliver, and John Moore. "Default and renegotiation: A dynamic model of debt." Quarterly Journal of Economics 1998, 113, pp. 1-41.

Hart, Oliver, and John Moore. "A Theory of Debt Based on the Inalienability of Human Capital.” Quarterly Journal of Economics, 1994, 109, pp. 841-879. 
Hellman, Thomas and Manju Puri. "The interaction between product market and financial strategy: The role of venture capital.” Review of Financial Studies, 2000, Winter, pp. 959-984.

Hellman, Thomas and Manju Puri. "Venture capital and the professionalization of start-up firms: Empirical Evidence.” Working paper, Stanford Business School, September 2000.

Holmström, Bengt. "Moral Hazard and Observability." Bell Journal of Economics, 1979, 10, pp. 74-91.

Kaplan, Steven and Per Strömberg. "Financial Contracting Theory Meets the Real World: An Empirical Analysis of Venture Capital Contracts.” Working paper, University of Chicago, March 2000a.

Kaplan, Steven and Per Strömberg. "How do venture capitalists choose and manage their investments?" Working paper, University of Chicago, September $2000 \mathrm{~b}$.

Lazear, Edward. "Salaries and Piece-Rates." Journal of Business, 1986, 59, pp. 405-431.

Lerner, Josh. "Venture Capitalists and the Oversight of Private Firms.” Journal of Finance 1995, 50, pp. $301-318$.

Quindlen, Ruthann. Confessions of a Venture Capitalist. New York, NY: Warner Books, 2000.

Repullo, Rafael, and Javier Suarez. "Venture Capital Finance: A Security Design Approach." Working paper, CEMFI, 1999.

Sahlman, William, 1990, “The Structure and Governance of Venture Capital Organizations.” Journal of Financial Economics, 1990, 27, pp. 473-521. 


\section{Endnotes}

${ }^{1}$ For a recent summary, see Hart (2000).

${ }^{2}$ See Gompers and Lerner (1999).

${ }^{3}$ For earlier, related work, see Sahlman (1990), Gompers (1998), and Black and Gilson (1998).

${ }^{4}$ For example, see Gladstone (1988) or Quindlen (2000).

${ }^{5}$ See Garmaise (1999) for a theoretical model that makes the latter assumption.

${ }^{6}$ For example, see Gorman and Sahlman (1989) or Quindlen (2000).

${ }^{7}$ See Repullo and Suarez (1999) for a theoretical treatment along these lines. 